\title{
The Longman by-election of 2018: An ordinary result with extraordinary consequences
}

\author{
John Mickel and John Wanna \\ rjohn.mickel@gmail.com,john.wanna@anu.edu.au
}

\begin{abstract}
This article sets out to explain how the relatively unremarkable 2018 by-election result in which a sitting Labor candidate held her seat with a mediocre swing towards her resulted in the panicked removal of Prime Minister Malcolm Turnbull from office and his immediate resignation from the parliament. The combined Queensland state Coalition party, the Liberal National Party, convinced itself that it could win the marginal outer-metropolitan seat of Longman in Queensland but when its expectations were dashed, it became spooked and set in train a chain of events that ousted Turnbull and installed Scott Morrison as prime minister. Turnbull was widely seen by the Coalition party room as having run a lack-lustre campaign in the 2016 federal election, and not having performed well in the 2018 by-election campaigns. Perhaps unwisely, Turnbull made the Longman by-election a direct leadership contest between himself and opposition leader Bill Shorten. However, Labor's tactics in the by-election 'outmanned, outspent and out-campaigned' the Coalition's faltering campaign in the seat, causing the relatively unremarkable outcome in Longman to become a catalyst for a challenge to Turnbull's leadership. When parliament reconvened, Peter Dutton became the 'stalking horse' who resulted in the rise of Scott Morrison to the top office.
\end{abstract}

\section{The significance of the Longman by-election}

How did a relatively benign swing against the Coalition government in a Queensland by-election bring down the elected prime minister of Australia? The answer lies in a strange concoction of contributing factors and seemingly unconnected triggers. These included the strange dynamics of the campaign waged by the major parties over the by-election, the serial miscalculations of the principal politicians involved and, simultaneously, the clandestine machinations taking place among federal Liberal parliamentarians. The Queensland by-election in the seat of Longman shaped Australian politics in late 2018 and early 2019, inadvertently becoming a catalyst for yet another momentous leadership challenge without reference to the people. 
As both Niki Savva and David Crowe have argued, the 'lack-lustre' performance of the Coalition in Longman 'precipitated the coup' against Malcolm Turnbull in August 2018. ${ }^{1}$

The Longman by-election was held on 28 July 2018 because the first-term Labor member, Susan Lamb, had not fully relinquished her dual citizenship. It was one of a series of five by-elections held on the same day in Tasmania, South Australia and Western Australia. Four of these were held for similar reasons as the 'parliamentary eligibility crisis' continued to unfold because three Labor members and an Independent were deemed entitled to hold dual citizenship and so therefore disqualified under section 44(i) of the Constitution. ${ }^{2}$ The High Court had been interpreting this section literally, relying on the ordinary meaning of the words 'entitled to the rights or privileges of a subject or a citizen of a foreign power', and already eleven federal parliamentarians had been ruled ineligible since the July 2016 election because they had not sufficiently renounced their entitlement to dual citizenship. ${ }^{3}$ Dubbed 'Super Saturday' by the media, in the end all five seats were unremarkably retained by their respective parties. The political impact of the Longman result was profound, however, because it heralded the political downfall of Prime Minister Malcolm Turnbull - the sixth prime minister to have been ousted from office in eleven years.

The Turnbull government had been narrowly re-elected with a massively reduced majority in the July 2016 federal election. It preserved its majority by holding on to two earlier by-elections caused by the eligibility crisis - New England and Bennelong. In May 2018, the government had introduced its 2018-19 Budget offering tax cuts and by July, according to Newspoll, was ahead of Labor in the primary vote by 39-37 per cent and later in July by 39-36 percent (28 May 2018, 18 June, 2018, 1July and 29 July 2018; see also Pollbludger.net 2008/07). However, for most of the month the Coalition trailed Labor 51-49 per cent in the notional two-party preferred vote. The by-elections provided the Coalition government with the possibility of increasing its one-seat majority in the parliament by either capturing one or more of the marginal Labor seats - Longman or Braddon - and/or recapturing the traditionally conservative South Australian seat of Mayo. Certainly by early July, all major national polling indicated a trend line for Labor holding 51 per cent of the two-party preferred vote (Newspoll, 8 April 2018, 22 April, 13 May, 28 May, 18 June, 1 July and 15 July 2018); Bowe, 28 July 2018). Nevertheless, by then Labor's vote appeared to have flatlined. To compound the problem for Labor, by July 2018 the satisfaction level of the two leaders had shown its widest gap to date (by 19 points) in the Newspoll data (Newspoll, 15 July 2018). Malcolm Turnbull had established a clear ascendancy over opposition leader Bill Shorten. This was a confidence boost for the government and the main parties immediately went into intensive campaign mode, as did the supporters of Rebekha Sharkie in Mayo.

Two of the Labor by-elections attracted the most intense scrutiny because of the narrowness of the margins by which the incumbent held the seat - Longman on a knife-edge of under 1 per cent and Braddon by 2.2 per cent. ${ }^{4}$ Longman in particular soon became regarded by the national media as a litmus test of Bill Shorten's leadership (and he personally made eight visits to the seat during the campaign). Were he to lose a marginal Labor seat, his colleagues would increasingly fear that he could not gain sufficient momentum to bring Labor to victory at the next election, which at the time was widely expected to be called either in late 2018 or before June 2019. ${ }^{5}$ Much political jockeying in the lead-up to the Longman by-election 
concerned Shorten's unpopularity as opposition leader, as a former AWU official with a history of 'shiftiness' and 'Machiavellian duplicity' (an issue highlighted in the ALP's review of the 2019 election: ALP, 2019: 24-5). Press reports argued that if Labor lost Longman, it 'could mortally wound Bill Shorten's leadership' (Owens, 2018b: 9). Graham Richardson (2018: 4) opined that, 'Shorten will cop the blame for any Labor loss in Longman. His leadership will come under immediate scrutiny if Longman falls and he knows his neck is probably on the line.' Some media speculation mischievously questioned whether his rival, the Left's Anthony Albanese, would assume the mantle in a last-ditch attempt to refresh the Labor brand. There was even a You. Gov Galaxy poll, published in The Australian of 24 July, that suggested Albanese would lift Labor's vote by 4-6 per cent, as well as other media that suggested Albanese would lift Labor's vote more than Shorten (Sky News, 28 July 2018). Labor rallied around Shorten in the wake of the poll. Arguably, since Shorten had assumed the leadership in 2013, his shadow ministry and caucus were comparatively united (compared with the Rudd-Gillard era), had strategically picked its political fights and had become decidedly forthright in new policy development. Yet, as Savva (2019b: 12) subsequently maintained, party unity under Shorten was not without its downsides - stifling internal constructive criticism and leading to 'arrogance, hubris and absolutism'. Labor opted to contest the next election with an ambitious policy platform explicitly framed around redressing inequality and demonising the banks and big business (and so not resorting to another 'small target' approach). But Shorten's credibility as leader was still seen to be a problem and a significant campaign issue in failing to attract swinging voters, especially women (Newspoll, 1 July 2018).

\section{Longman's characteristics, demographics and electoral history}

The seat of Longman is classified by the Australian Electoral Commission (AEC, 2018) as 'provincial'. It is an outer metropolitan electorate north of Brisbane, centred on Caboolture, the satellite towns along the Bruce highway from Burpengary to Beerburrum, spreading out along the Woodford and Stanley valleys, through Samsonvale, and including the half-dozen retirement neighbourhoods and holiday homes on and around Bribie Island. The federal seat effectively straddles the northern outer suburbs of Brisbane with its southern boundary backing onto Redcliffe, Petrie and Strathpine. In many ways, Longman has all the characteristics of a sprawling outer-metropolitan seat that serves as a dormitory to Brisbane and the inner metropolitan area.

The seat of Longman was proclaimed in 1994 as Queensland's population surged due to interstate migration, and faced its first election in 1996. In the eight federal elections since the seat was created, Longman has changed hands three times and had four members. Mal Brough, a local notable Liberal and a minister in the Howard government, held it for 11 years or four parliamentary terms. He lost to a former state Labor member, Jon Sullivan, in 2007. Sullivan held on for one term and lost to Wyatt Roy (LNP), who survived just two terms (2010-16). Roy then lost to Susan Lamb at the 2016 federal election. In short, the seat displayed acute electorally volatility with three new federal members in nine years. By 2018, Longman had an enrolment of 111,784 registered voters with a turnout based on 2016 election figures of 91.7 per cent and an informal rate of voting of 8.53 per cent. It was an archetypal marginal seat, highly volatile with little party 
loyalty and low 'party identification' across the electorate. In essence, the seat displayed no consistent pattern of voting; it was too new and too fast growing to have the stable electoral behaviour of a safer seat.

Geographically, Longman - which sits mainly within the Moreton Bay Regional Council region - can be subdivided into three distinct communities of interest, each with different demographics and traditional loyalties. These separate communities display different patterns of voting across the seat: two are conservatively inclined and only the heavily populated centre of the electorate favours Labor (Owens, 2018b: 9). The first group comprises the coastal communities on the east, consisting largely of retirees and 'sea-changers' located along Deception Bay and on Bribie Island. The second is made up of the commuter residents and manual workers in the service centres along the Caboolture-Morayfield-Burpengary central corridor. Third, the northern-western hinterland consists of small villages and families sitting on small-holdings. Many residents of Longman were attracted to the area because of the affordable 'house-and-land' speculative deals offered by land developers, and most had moved there within the last 20 years. Many electors were regular commuters who spent hours in daily commuting to Greater Brisbane, with one rail line and a highly congested Bruce Highway running from north to south.

A very high proportion of Longman residents were born in Australia (82.6 per cent), with only 2.7 per cent being from an Indigenous background and 17.4 per cent born overseas. Demographically, the seat has remained a relatively homogenous Australian electorate, attracting relatively few migrants or different ethnicities. According to the Queensland Parliamentary Library, of the 150 federal electorates, Longman ranked 102 in terms of people born in Australia. In workforce terms, 57.5 per cent were in full-time employment, with 29.1 per cent in part-time jobs and 7.3 per cent unemployed - slightly above the national average. Almost 40 per cent of those in the electorate worked as tradespeople, labourers or machinery operators and drivers. Most owned or were buying their homes, with 65.7 per cent owner-occupiers and 31.2 per cent renting. Median weekly household income was just $\$ 1,103$, or $\$ 57,356$ per annum, which meant Longman ranked 111 out of the 150 federal electorates (AEC, 2018). In educational achievement, Longman ranked 147 out of 150 for the lowest attainment of university graduation (12 per cent against an Australian average of 23 per cent), and the electorate had a median weekly household income below Australian average and a below average proportion of foreign-born residents (17.4 per cent against an Australian average of 23 per cent). This demographic mix was both receptive to Pauline Hanson's One Nation messaging and attracted to Shorten's Laborite 'anti-inequality agenda' and health commitments that were emphasised during the by-election campaign.

In 2013, the Liberal National Party (LNP) defeated Labor in the federal election and won the seat of Longman by 56.92 per cent to 43.08 per cent on a two-partypreferred basis. Labor won just seven of the 37 polling booths, with support mainly corralled into Caboolture and Kallangur. The Coalition performed best in the beachside suburbs of Bribie Island, Donnybrook, Burpengary, parts of Caboolture, Narangba, Woodford and even parts of suburban Morayfield. By contrast, Labor performed much better in 2016, attracting a swing of 7.71 per cent, thereby winning 20 of the 32 booths and coming within 2 per cent in another five, plus winning the absentee votes while losing the pre-polling votes. Labor's new heartland was centred on Caboolture (where it convincingly won all five booths), Burpengary, 
Kallangur, Morayfield and Narangba. Accordingly, the seat was taken in 2016 by Labor's neophyte Susan Lamb by a slim margin of just 0.79 per cent.

\section{Candidates for the 2018 by-election}

In the 2016 general election, eleven candidates stood for Longman - exactly the same number that had stood in the 2018 by-election. Susan Lamb was the only candidate who stood in 2016 and again in 2018; the rest were largely novices nominating for the first time. Her main challenger was Trevor Ruthenberg, a former Air Force fitter known locally as 'Big Trev', who was a former state LNP member representing Kallangur for one term (from 2012 to 2015). Getting into parliament at the landslide 2012 election was not a serious test of his appeal as a local candidate, and the overlap between the state and federal seats was not large. Ruthenberg had served in the Campbell Newman LNP government and so was partially tainted by this association. The rest of the by-election field consisted of an array of candidates, one each from One Nation, the Greens, a solitary Independent, the Liberal Democrats, the Australian Country Party, the Democratic Labor Party, the Science Party, the Australia First Party and the People's Party (whose primary votes finished in that order). The Liberal-Democrat candidate headed the ballot paper, with One Nation sixth, Labor eighth, the LNP ninth and the Greens last on the ballot paper.

\section{The dynamics of the local campaign}

With over eight weeks allowed for campaigning, Labor attempted an orchestrated, energetic and multi-dimensional campaign strategy. An army of red-shirted volunteers, unionists and branch members was bussed into the electorate, providing saturation-style local momentum and much media coverage (Lewis and Maher, 2018). In addition, a cavalcade of Labor leaders and other luminaries visited the Queensland seat, altogether managing to promise some $\$ 155$ million in new spending to go to the electorate (compared with $\$ 45$ million from their LNP opponents) (McKenna and Lewis 2018). Lamb was relatively passive in campaigning, sidelined for photo opportunities and playing the nodding TV backdrop with visiting Labor dignitaries. Labor stressed that she was a 'battler' and a 'single mum', but the party was also relying on a sympathy vote, believing some within the electorate would appropriately vote Lamb back into parliament perhaps because the dual citizenship fiasco was not necessarily perceived to be her fault.

By contrast, the LNP's campaign was generally low-key and underwhelming. The party was slow to commence the campaign proper, it seemed devoid of a 'cutthrough' message and at times it appeared amateurish with a few juvenile slogans aimed at the Labor leader Bill Shorten and his candidate. ${ }^{6}$ The LNP was hesitant to settle on a preferred candidate to challenge the incumbent (ostensibly due to a 'lack in interest' from potential candidates (Remeikis, 2018). Finally, the party turned to Trevor Ruthenberg on 22 May, but even then did not seem to have sufficient campaign funds to run a high-visibility campaign or build local enthusiasm. Moreover, Ruthenberg as a candidate was hardly blemish-free, and would soon mar his own campaign with an embarrassing error. It was widely reported in the 
media that he had claimed a Defence 'service medal' to which he was not entitled, having served in the forces for over four years as an aviation technician but not in overseas peacekeeping operations or on active war service.

Shaping the campaign was a series of local polls showing that the electoral situation for Longman was dire. The ABC Longman by-election site (2018) summarised the campaign in the following terms:

A Sky News/ReachTEL poll in early June reported a two-preferred lead for the LNP of 52 per cent to 48 per cent for Labor.

A ReachTEL poll commissioned by the Australia Institute and published on $24^{\text {th }}$ June had the result deadlocked at 50-50.

Another ReachTEL poll commissioned by The Courier-Mail and published on $28^{\text {th }}$ June produced a two-party preferred of Labor 49 per cent, LNP 51 per cent, and reported One Nation's support as close to 15 per cent.

A You. Gov Galaxy poll reported in News Limited local papers on 23July had first preference results of Labor 37 per cent, LNP 34 per cent, One Nation 18 per cent and Greens 5 per cent. After preferences, the LNP would lead 51 per cent to 49 per cent. If the LNP did win in this manner, it would be the first time One Nation preferences had overturned a Labor first preference lead in a federal electorate and delivered victory to the Coalition. A second question based on Anthony Albanese being Labor Leader would have delivered Labor victory 53 per cent to 47 per cent.

The pressure on Labor's leadership arising from the publication of these polling findings was twofold. It reinforced the sense of a widening gap in satisfaction ratings between the opposition leader and Prime Minister Turnbull, and by including Albanese in the poll, it included a possible Labor leadership contender.

Malcolm Turnbull visited the electorate in mid-July and proclaimed, perhaps injudiciously, that the by-election in Longman was a 'contest between me and Bill Shorten as the prime minister and the opposition leader' (SMH, 29 June 2018; Guardian, 11 June 2018, a statement repeated on ABC radio the same day). With the wisdom of hindsight, he may have regretted elevating the odds so dramatically. Nevertheless, his clear intent was to place Shorten's apparent unpopularity at centre stage in the local campaign. ${ }^{7}$

One 'local forum' or debate between the main protagonists was conducted, although the LNP kept challenging Lamb to appear at others that were held in community clubs across the electorate. One local issue of note was the supposed federal cuts to the public hospital in Caboolture, a claim denied by the Turnbull government but repeatedly asserted by Labor and reinforced with mobile billboards touring the electorate (leading some campaign watchers to dub the tactic as 'Mediscare Mark II'). ${ }^{8}$ Shorten claimed at the campaign launch on 22 July that the Liberals' legislated tax cuts would 'cut $\$ 17$ billion from schools'. Ruthenberg also seemed to deny climate change was occurring in answers to audience questions at public meetings. Other factors such as Catholic voters preferring to vote for Labor over the so-called cuts to Catholic schools appeared to have had a negligible effect.

A further factor in Lamb's favour was her personal vote, which although still small would have held up support for her as the sitting member. She had been the local member for two years and would have built up some voter recognition. 
Presciently, the amateur psephologist Kevin Bonham offered this explanation on his blog site:

In trying to frame the Longman by-election, the first point from by-election history is that by-elections contested by Governments in Opposition-held seats have an average swing of 1.1 per cent to the Opposition. However, there is a relationship between that swing and the national 2PP polling at the time. Based on my present aggregate (as adjusted for One Nation preferences) the expected swing would be 1.8 per cent. However, voting intention has been swinging rapidly to the Coalition in recent weeks and by Election Day the expected benefit might be less.

The second point in Susan Lamb's favour is personal vote effects. Normally, an Opposition seat by-election would involve the loss of an Opposition personal vote. In this case that isn't an issue, so we should expect the swing to Labor to be about a point greater, all else being equal ... Lamb has held the seat for two years and in that time would have built up some personal vote, but not as much as for a full parliamentary term. Lamb defeated Wyatt Roy, who would have also built up some personal vote over two terms in office (although also a liability in preference terms, which I will come to later). The LNP candidate Trevor Ruthenberg is a former state MP for the overlapping (now abolished) seat of Kallangur, but the overlapping portion isn't very large, and his profile would have reduced over two years anyway. So it seems fair, all else being equal, to give Lamb about 1.1 points in assumed personal vote effects (compared to the standard 1.4 points for a sophomore surge at a normal election according to Poll Bludger) ... We now have Lamb [expected to gain] $50.8+1.8+1.0+1.1=54.7$ per cent. $^{10}$

This campaign analysis from Bonham all but predicted the eventual outcome. Therefore, based on Bonham's analysis of an assumed 54.7 per cent to Lamb and the final result of 54.4 per cent to Labor, the local campaign appears to have made very little difference. Longman was probably subsumed by the prevailing national mood, the absence of the former member Roy as a candidate and a small personal factor for Lamb as the current sitting member.

\section{Framing Longman as a leadership contest}

Prime Minister Turnbull somewhat puzzlingly framed the Longman by-election specifically as a leadership contest between himself and opposition leader Bill Shorten, partly to shore up his credentials as the Liberal leader. The reasons for this sudden escalation are complex but not entirely inexplicable. Perhaps it was down to over-confidence exacerbated by repeated published polling showing that the prime minister had a better satisfaction rating and was the preferred leader over the opposition's Bill Shorten. With the polls showing Shorten as unpopular, the government had for some months sought to capitalise on this advantage by initiating a 'Kill Bill strategy' both within and outside the parliament. Prime Minister Turnbull's declaration that the by-election was a personal contest between himself and opposition leader Shorten was a further extension of this strategy.

The mainstream media, led by News Corp, and by Fairfax in the Australian Financial Review, had enthusiastically supported this de facto leadership campaign, with the latter claiming the by-election was a 'referendum on Malcolm Turnbull and Bill Shorten' (Ludlow, 2018). At the same time, the media continued to promote the 
idea that shadow spokesman Anthony Albanese was the opposition leader inwaiting - a notion not entirely rejected by Albanese, who gave a 'not so veiled swipe at Bill Shorten and his awkward class-war rhetoric' (Ravens, 2018). Hence, media encouragement of the presidentialised contest was another contributing factor, but it ignored political reality. The opposition leader's position was, in fact, jobprotected by caucus rules restricting a leadership coup. The returning Labor Prime Minister, Kevin Rudd, had introduced these changes in 2013 as a price for accepting the Labor leadership.

With hindsight, the prime minister's framing of the Longman by-election outcome was ill-advised for two basic reasons. First, no government had won a by-election seat from the opposition in Australia for over 90 years and the circumstances of the Longman by-election seemed at odds with overturning that history. Second, the Sydney Morning Herald's leading political columnist, David Crowe, claimed that the Liberal Party had carried out a benchmark poll in May and a spot-poll in July, and both results were substantially in line with the final tally (Crowe, 2018). He also argued 'that the polling made no case for a major shift in government direction and said there should be no shock at the Coalition losses in the Longman and Braddon by-elections'. Internally, the government knew an electoral upset was a slim prospect (see also Crowe 2019: 181).

Taken together, these views highlight a significant political miscalculation of the likely outcome of the by-election. Moreover, framing the expected result around leadership was a high-risk strategy, possibly reckless and ultimately a politically fatal decision for the prime minister.

Turnbull, however, was encouraged in this tactic by News Corp and an array of ReachTEL and robo-call polls. Indeed, of the six published polls taken in the leadup to polling day, five showed the LNP leading in Longman on a two-partypreferred basis by one to two points, with one poll showing a draw at 50-50 per cent two-party preferred. ${ }^{11}$

Third, there was a view within the LNP that the Labor win in Longman at the 2016 general election was an aberration occasioned by the One Nation preference flow to Labor. ${ }^{12}$ As Peter Brent (2018) observed, 'One Nation's 9.4 per cent primary vote flowed 56.5 per cent to Labor and 43.5 to the Liberal National Party (LNP). That translated to a net gain of 1.2 per cent for Labor's Susan Lamb, more than her winning margin of 0.8 per cent.' After the One Nation Leader, Pauline Hanson, had decided to preference the LNP ahead of Labor in the Longman by-election, it was assumed that her winning margin at the general election could easily be reversed. ${ }^{13}$ Such thinking inside the LNP, along with belief in the optimistic public polling and the positive gap in leadership approval ratings, encouraged overreach about framing the by-election around the national leadership.

A more politically astute approach would have seen the prime minister arguing the strength of the government's economic credentials, taking aim at Shorten for the false assertions he had made about the undisputed eligibility of his entire caucus in the dual citizenship saga and down-playing a possible government victory in media coverage. More broadly, there was a need for judicious caution, given that two neighbouring federal electorates traversing Longman's border were also highly marginal Coalition seats: Peter Dutton's seat of Dickson (held by 2 per cent) and Petrie held by Luke Howarth (on a margin of 1.7 per cent). 
These highly marginal Coalition seats on Brisbane's outskirts point to a bigger issue for the Queensland LNP facing challenges to their voter base. For sitting members, like Dutton and Howarth, the biggest threat to their ability to hold onto their seats is not Labor per se, but rather the spasmodic insurgency from the right the likes of Pauline Hanson, Bob Katter, Clive Palmer and Cory Bernardi, all in varying stages of ascendency - capturing parts of the conservative vote and scattering preferences erratically.

Dutton was one of the key leaders of the federal Liberals' right-wing faction who barely tolerated Malcolm Turnbull: any suggestion of a poor Liberal result, especially one around leadership, would have ultimately triggered a leadership challenge.

In the early evening of polling day, as the two-party booth count became apparent, the prime minister was let down by the flat-footedness of the Queensland LNP in response to Labor's election night spin. Labor was able to claim that its candidate had received 40 per cent of the vote while the LNP vote was marooned in the mid-20 per cent range. This was certainly true at the close of counting on the Saturday night. However, in subsequent days the Liberal primary vote drifted upwards to finish on 29.61 per cent, compared with Labor's vote, which slipped under 40 per cent (39.84 per cent). Although the LNP president Gary Spence had enjoyed a reasonable relationship with Turnbull prior to the by-election, his immediate comments that the prime minister was deeply unpopular in Queensland, and that LNP MPs should back Dutton if there was a leadership spill in the coming weeks, also fed into the sense of despair at the result and inflamed the Queensland right.

A more sympathetic LNP state executive could have highlighted that the party had not performed well in the electorate in the 2017 state election. It could have accurately argued that its by-election primary vote showed an increase of 5 per cent on that result with Labor's primary vote down 1.5 per cent on the same result. This would have given context to the difficult electoral territory that this area represented for the LNP. It could have been presented as Turnbull being an asset to the LNP vote. All of this was missing from the post-election analysis; hence Turnbull's active involvement in Longman did not translate into an improved Coalition vote but instead became the catalyst for his removal.

\section{The effects of polling techniques on modern campaigning}

Digital disruption affecting the media has had direct consequences for election campaigning. The decline in print media advertising, a steady decline in readership or media consumption and the resultant loss of experienced journalists have resulted in time and resource pressure on print media in democratic nations, especially in the age of Twitter, the internet and the 24/7 news cycle. As veteran Canberra journalist, Laurie Oakes (2013: 11-12) observed, there are no fixed 'deadlines' anymore; rather, there are deadlines every nanosecond. This accelerated style of reporting has produced what Oakes terms 'attention deficit disorder' in relation to issues and the news.

To combat this disruption, the established print media has sought in recent decades to set the news agenda in election campaigns by the release of polling carried out by automated telephone calls. The ReachTEL organisation was 
commissioned by numerous clients to conduct robo-polling in Longman over the by-election campaign. Longman was targeted by the established media because they considered that this would be the most likely government gain.

Analysis from the United States (Johnson, 2010: 69) shows that participation in telephone surveys, such as those conducted by ReachTEL, has witnessed declining response rates in recent years from 60-70 per cent to less than 30 per cent. Hence, it is harder to secure sufficient participation that is statistically significant and also harder to have the correct demographic mix needed for a reliable sample. Technological advances are also playing a role in nullifying a correct weighted sample including the prevalence of answering machines, call blocker technologies and the frustration and impatience of people regarding unsolicited phone calls. Veteran US pollster Mark Mellman (cited in Johnson, 2010: 71) called this phenomenon 'the demise of the landline lifecycle phenomenon'. He concluded, 'Those who are young, single, childless, living with unrelated room-mates and mortgage-less are likely to be cell phone only while older, married parents who own homes retain land lines.'

Mobile phones as a polling tool are just as limited. Analyst Dennis Johnson (2010: 71 ) suggests that mobile phones are not conducive to thoughtful conversation. They can be answered anywhere - in restaurants and cafes, on buses, in classrooms; students can be on campus, away from home or interstate. Applying such logic to Longman might account for the polling inaccuracy. After all, Longman's residential areas contain older, settled demographic areas along the coast and north-west (much more likely have a higher rate of telephone landlines), with younger families and singles cloistered in the central areas of the electorate (the classic mobile phone demographic). Historically, older settled areas were more conservative in their federal voting intentions, while the new dormitory suburbs were more likely to have swinging and Labor voters.

Hence, polling purely from landline calls will tend to over-represent the LNP and under-represent the Labor vote, which appears to have happened in the Longman by-election. The Longman case is consistent with research into published polling in individual electorates conducted by Jackman and Mansillo (2016), who found that the LNP vote was overstated and the Labor vote understated in polls.

Another weakness in the reliability of automated phone polling is the inability to accurately distribute preferences. These polls cannot accurately capture the preferences of all the candidates - in Longman's case, there was a large field of 11 candidates - the phone pad does not allow choices of this number of candidates to accurately capture the likely flow of preferences. Inevitably, preference distribution assumptions were drawn from previous elections, which can prove inaccurate.

The lifeblood of modern campaigning is assembling accurate data - on contact numbers and addresses, on the types of issues in which people are interested, on age group, gender, income and ethnicity. The second ingredient is the money to execute the campaign plan after interpreting the data. Any campaign with a modern database starts with a huge advantage, and Labor used that in Longman with a massive volunteer effort.

A feature of all modern campaigns is the use of volunteers to telephone voters. In a sprawling electorate like Longman, it is now used in addition to the traditional contact method of door-knocking. Telephone banking helps identify party supporters or party opponents. This then helps target either email contact or direct post mail to those voters on the issues they have raised. It also means that precious funds 
are not spent on the party's opponents. With supporters, it galvanises enthusiasm for their candidate. In Longman, Labor's volunteers reportedly knocked on 35,870 doors and made 73,180 telephone calls, and up to 100 union officials participated in the campaign. In addition, the political action Group Getup! made 27,000 telephone calls calling for action against the Turnbull government (Lewis and Maher, 2018).

In the Longman by-election, another promotional technique used by the major parties was robo-calling with targeted messages. A robo-call is a radio advertisement delivered as a one-way message down a phone line, either from the leader urging the voters to vote for their candidate, or from the candidate urging voters to support them, and occasionally another known personality urging voters not to vote for someone. In the Longman by-election, the former Labor leader, Mark Latham, was reported as having being used in robo-calling against opposition leader Bill Shorten (ABC, 2018). However, research cited by Don Green (Jack the Insider, 11 July 2018) concluded that robo-calls have no mobilisation effect and no persuasive effect. This was supported by a direct marketing expert, Kim Fai Kok, who found that 93 per cent of recipients did not want or like robo-calls.

Taken together, the inaccurate polling techniques and the (probably) ineffective campaign strategies fed into a false sense of security for the Coalition, and hardly changed the vote for Labor beyond what had been already been predicted by psephologists or benchmark polling.

\section{The results - not a complete surprise to the main protagonists}

On 'Super Saturday', Labor's two most vulnerable seats recorded an extremely modest swing of 0.1 per cent in Braddon and a modest swing of fewer than 3.66 per cent in Longman. At the close of counting, the Longman result produced at best a modest result for Labor. Lamb recorded a +4.46 per cent swing towards her on the primary votes (35,203 votes), while Ruthenberg suffered a massive 9.4 per cent swing against him, securing only 26,170 votes. In fourteen of the thirty-three local electoral booths, Labor secured a swing of greater than 10 per cent, with the highest swings occurring in Donnybrook (13.34 per cent) and Burpengary (13.27 per cent) (Figure 1).

In two-party-preferred terms, Lamb won by 54.45 per cent to the LNP candidate's 45.55 per cent. In the distribution of preferences from the other nine candidates, Lamb won 12,913 of the subsequently transferred votes, mainly from the Greens (76.52 per cent of 3,263 transferred votes) and a few minors (DLP, Australia First Party, Australian People's Party). Ruthenberg managed 14,082 from the conservative side - mainly from One Nation (with 67.74 per cent of 9,525 transferred votes) plus some from Independents, fellow conservatives and over 1000 votes from the Greens. Interestingly, One Nation's preferences that determined the final result went 39.52 per cent to Labor and 60.48 per cent to the LNP - but were not sizeable enough to secure a conservative win.

With the Liberal candidates not able to gain a positive swing in either Longman or Braddon (where the Labor candidate eventually scored a smaller 0.11 per cent swing towards her), the Labor opposition was quick to crow about its success in holding its four seats. The political pressure quickly switched from questioning Shorten's leadership to questioning Turnbull's electoral appeal. Having made the 


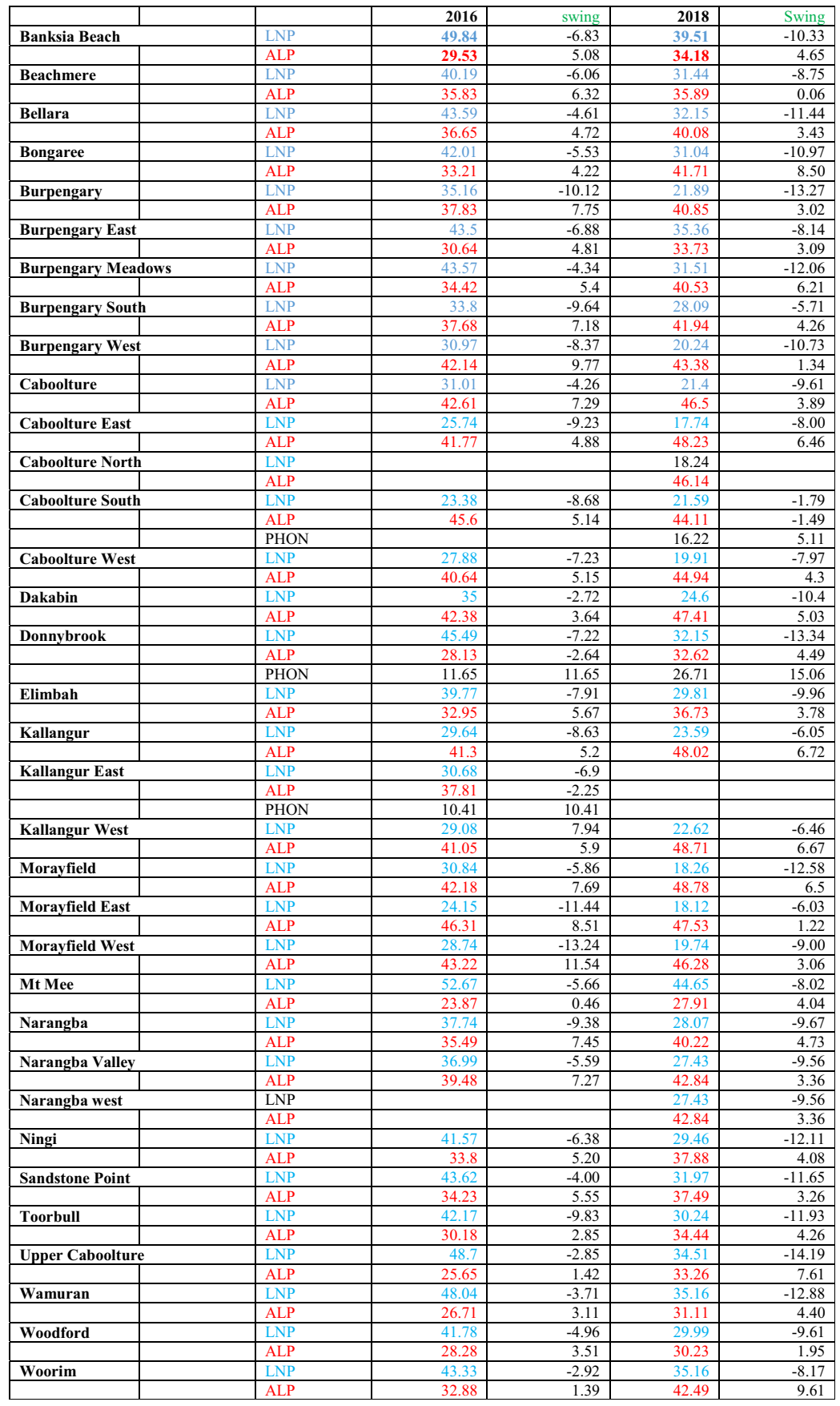

Figure 1

Changes in the booth primary vote for Longman in the general election of 2016 compared with the by-election of 2018

\section{4 【ueensland Review}


contest about leadership, the prime minister had to expect that his opponents in the party would use the results against him.

\section{Why the sudden move against Malcolm Turnbull?}

Longman's result shifted the political narrative from pressure on Bill Shorten to discussion about the leadership credentials of the prime minister. Malcolm Turnbull was destined to face the wrath of the right wing of his party, News Corp and the cabal of right-wing commentators on Sky TV for his leadership failure, having made that the pre-eminent issue in the campaign. The wrath then shown was a hangover from the successful leadership challenge against former Prime Minister Tony Abbott and the transactional cost of the contest. Policy failures by Turnbull, such as the doomed National Energy Guarantee in 2018, had lowered his standing among his colleagues, and the refusal to countenance the inclusion of Abbott in the second Turnbull ministry only added fuel to the discontent (Hartcher, 2019a; Savva, 2019a).

Sydney Morning Herald journalist Peter Hartcher (2019b) analysed the Longman by-election, claiming it was:

a threshold moment where the LNP's share of the vote in Longman fell by a jolting 10 percentage points. Over two elections it had fallen a sickening 16 percentage points. If the government went to an election and lost just one-fifth as many votes in its other Queensland seats, it would be wiped out. The Longman result drained hope from the government.

The Liberal Party's despair from Longman was summed up in The Australian as 'outmanned, outspent and out campaigned' (Lewis and Maher 2018; see also McKenna and Lewis 2018).

The Longman result reminded Malcolm Turnbull's Liberal enemies of his 2016 federal election campaign, which his potential rival, Peter Dutton, had described as 'the worst campaign I have ever seen', damning him further by claiming Turnbull was 'hopeless at politics' (Hartcher, 2019a). In the 2016 campaign, Turnbull had run his own campaign from his office with his close advisers. He disregarded the Liberal Party organisation's efforts and the planned schedules of its formal campaign director. He did not adequately rebuff Labor's 'Medi-scare' campaign, which cost the government thirteen seats to Labor, one to an Independent and the safe seat of Murray to the National Party, nor did he cut through with his message about having an 'economic plan', which may have appealed to the Liberal heartland but less so to swinging voters.

Even with this result, the government's parliamentary majority was never under threat, with the Coalition holding 76 seats to Labor's 69, and with a number of friendly Independents who would support the Coalition in a no-confidence motion. Two earlier (dual citizenship inspired) by-elections held in 2017 had seen seats safely returned to the Coalition, with the Nationals recording a 7 per cent swing in their favour in New England while the Bennelong by-election saw a 5 per cent swing against the Coalition.

After Longman, the right wing of the Liberal Party led by Peter Dutton felt sufficiently emboldened to publicly air the disgruntlement that had never dissipated since the demise of Tony Abbott (Crowe 2019). Home Affairs Minister Peter 
Dutton, who along with fellow MP Luke Haworth had worked the booths all day in Longman, then tapped into the mood that was already fomenting in the right wing of the Liberal Party. There was also speculation that Dutton had told colleagues he intended to challenge Turnbull as early as late 2017 according to Mathias Cormann (Savva, 2019a: 22). As Peter Hartcher (2019a) observed, 'sometimes other conservatives would lose patience with Dutton and complain that he was too loyal, that he was propping up a leader they despised'. Publicly, Dutton remained loyal to Turnbull, but within days his loyal lieutenants were doing the rounds canvassing his leadership prospects. ${ }^{14}$

The leadership challenge atmosphere was agitated by Dutton favourites like 2GB's Ray Hadley, long-time Turnbull detractor Alan Jones and by the presenters on Sky News After Dark. The News Corp media, especially The Australian, tapped into the anti-Turnbull sentiment. The public broadcaster, the ABC, suggested that Malcolm Turnbull had fallen from favour with the main media barons, who began to use their media empires campaign against him. The ABC claimed that Turnbull had been undermined by Rupert Murdoch and Kerry Stokes - with Murdoch alleged to have said to Stokes, 'Turnbull had to go' (ABC News, 9 November 2018). Subsequently, Turnbull told the ABC's Q\&A program that 'according to Kerry [Stokes], Rupert said, "Oh, well, three years of Labor wouldn't be so bad", (SBS News, 9 November 2018).

\section{Conclusions}

By any objective measure, the by-election results offered mediocre swings against the government. The Longman by-election destroyed a prime minister because Turnbull elevated the seat contest to a leadership contest. Optimistic 'groupthink' within the LNP had the party believe that an unlikely victory was likely. The media had happily engaged in promoting it. Shock-jocks such as Alan Jones and Ray Hadley in Sydney captivated the LNP elected members by day, as did the ultraconservatives on Sky News After Dark. All these forces pushed an anti-Turnbull line - a transactional cost for the earlier overthrow of Tony Abbott as prime minister. A lack-lustre federal campaign by the Coalition in 2016 and even more lack-lustre results in the 2018 by-elections confirmed their view that Turnbull was a poor campaigner. Going into a by-election with his leadership as the most salient issue and coming up short meant that the anti-Turnbull forces were able to convince enough backbenchers that their futures were in jeopardy. It ignored the slight upturn for the Coalition and for Turnbull in the published opinion polls. It perhaps indicated that Liberal party elected members viewed the result from within the 'Canberra bubble', where right-wing commentators and their views overrode the views of the public.

There was little in the results of any of the 'Super Saturday' by-elections that would justify a move against a prime minister. Every seat that had been subject to a re-election under the dual citizenship section 44 of the Constitution saw the sitting member returned, so with a slight swing towards Labor, the Longman result was hardly exceptional. The best plausible explanation is that the Longman result was seen through the prism of leadership failure at the 2016 election, where the Coalition narrowly escaped minority government. 
The extraordinary events in mid-2018 led to the overthrow of Malcolm Turnbull and then to his departure from elected politics. This was followed by the exit of Julie Bishop from the ministry and her subsequent departure from politics. Other federal Liberals chose to quit the party or politics altogether following the bruising leadership contest and bullying of August 2018, including Julia Banks, Ann Sudmalis and Craig Laundy (and even more refused to recontest at the 2019 election, including Steve Ciobo, Christopher Pyne, Luke Hartsuiker, Andrew Broad, Michael Keenan and Kelly O'Dwyer). These significant departures represented a huge transactional cost for the Liberal Party with only months to go before a federal election that it looked likely to lose. Longman's aftermath meant that the Liberal Party entered an election cycle with an untested, less well-known leader, Scott Morrison, presiding over a factionalised and fractured party, still tearing itself apart. But Morrison later showed he was a far better 'stump campaigner' than Turnbull, and more in touch with electoral contours. For Labor's part, Bill Shorten managed to 'do a political Houdini' and seemingly miraculously escape a leadership challenge against his own leadership, despite the party's rules changed to prevent caucus revolts. Politics can indeed deliver a strange fate at times.

\section{Notes}

1 David Crowe (2019: 156-60, 165-6) argues that the Coalition received a 'thrashing' and that votes shifted 'ferociously' in the Longman by-election, whereas Niki Savva (2019a: 39, $41,255)$ argues that the large drop in the Coalition's primary vote crystallised 'discontent' and 'precipitated the coup'.

2 In a separate Western Australia case, the fifth by-election for July, the Labor member for Perth, Tim Hammond, had resigned for family reasons; this was unrelated to section 44 .

3 Parliamentarians caught up in the eligibility crisis included two Greens (Scott Ludlam and Larissa Waters), two Liberals (Stephen Parry and John Alexander), two Nationals (Barnaby Joyce and Fiona Nash), two from Labor (David Feeney and Katy Gallagher) and one each from One Nation (Malcolm Roberts), Palmer United Party (Jacqui Lambie) and Nick Xenophon's team (Skye Kakoschke-Moore). The four subsequent members whose eligibility was challenged included Susan Lamb, Justine Keay, Josh Wilson and Rebekha Sharkie.

4 The Western Australian Liberals did not stand candidates in the two Western Australian seats of Fremantle and Perth.

5 Shorten's leadership qualities had been widely questioned in the media since late 2017. Newspoll surveys had Shorten sitting between minus 15 per cent and minus 25 per cent satisfaction rating, well below Turnbull's satisfaction of between minus 5-10 per cent in the months before the by-election. An earlier electoral contest in 2018 had provided Shorten with some breathing space. When Labor's David Feeney succumbed to the dual citizenship eligibility test, he chose to resign rather than recontest his Victorian seat of Batman. To the surprise of many, on 17 March 2018 Labor managed to pull off a narrow win in the seat. Labor's candidate Ged Kearney (formerly head of the ACTU) beat the recontesting Greens candidate Alex Bhathal by a slim margin of 4.4 per cent (but with a lower primary swing to Labor) and without the Liberals standing any candidate. While commentators claimed Kearney only won because she wasn't the hapless and unpopular Feeney, the outcome helped to shore up Bill Shorten's leadership in the short term.

6 To combat Labor's apparent momentum, the normally sombre LNP coined a couple of droll campaign advertising slogans. One went, 'Order the Lamb. Get the Bill. No Thanks', 
and another: 'Silence of the Lamb' - a reference to the former Labor member's reluctance to appear at forums and in the media to answer questions.

7 Newspoll on 1 July 2018 had Malcolm Turnbull as the preferred prime minister by 46 per cent to Bill Shorten on 31 per cent; and Newspoll on 15 July 2018 recorded Turnbull at 48 per cent to Shorten on 29 per cent.

8 Jared Owens (2018a) reported Shorten arguing that 'Turnbull's cutting millions from Caboolture Hospital'. Labor's last-minute campaign launch on 22 July promised, 'We will make sure that we put back the $\$ 2.9$ million cut from Caboolture Hospital', ALP (2018).

9 Shorten in particular linked the Liberals' tax cuts to support for big business, the big banks and the 'top end of town', as well as criticising Pauline Hanson for supporting the measure in the Senate. Shorten mentioned $\$ 17$ billion in 'cuts' to services like hospitals, schools and TAFE colleges no less than seven times in his speech.

10 Kevin Bonham, blog site, 24 July 2018.

11 See ABC (2018 Longman by-election) and Bonham's election blog at kevinbonham. blogspot.com

12 Interview with LNP strategist, July 2018.

13 Interview with LNP strategist, July 2018.

14 Plotters included senior parliamentarians such as Tony Abbott, Eric Abetz, Greg Hunt, Mathias Cormann, Mitch Fifield, Steve Ciobo, Michael Keenan, Michaelia Cash and Angus Taylor. They were preparing for a Dutton premiership with Industry Minister Greg Hunt as his deputy on a conservative leadership ticket.

\section{References}

ABC News (various). ABC Online.

Australian Electoral Commission 2018. Seat of Longman, https://aec.gov.au.

Australian Labor Party (ALP) 2018. Bill Shorten's speeches, 22 July.

— 2019. Review of Labor's 2019 federal election campaign, Craig Emerson and Jay Weatherill. Canberra: ALP.

Bowe, William 2018. Poll-bludger, 28 July.

Brent, Peter 2018. 'The Longman and the short of it'. Inside Story, ABC, 14 May.

Crowe, David 2018. 'Liberal Party polling report warned cabinet against rash response to Malcolm Turnbull's leadership'. Sydney Morning Herald, 4 September.

- 2019. Venom, vendetta, betrayals and the price of power. Sydney: HarperCollins.

Hartcher, P. (2019a) 'Dutton's patient, careful game as part of Turnbull's inner circle', Sydney Morning Herald, 29 March.

- (2019b) 'How the Liberals got stuck in a long, demented cycle of vengeance', Sydney Morning Herald, 30 March 2019.

'Jack the Insider' (Peter Hoysted) 2018. 'Mark Latham is wrong: Robo-calls don't work and may have opposite effect', The Australian, 11 July.

Jackman, Simon and Mansillo, Luke 2018. 'The campaign that wasn't: Tracking public opinion over the 44th Parliament and 2016 election campaign', in A. Gauja et al. (eds), Double disillusion: The 2016 Australian federal election. Canberra: ANU Press.

Johnson, Dennis W. 2010. Campaigning in the 21st century: Activism, big data and dark money. New York: Taylor \& Francis. 
Kim Fai Kok 2010. 'Mark Latham is wrong: Robo-calls don't work', The Australian, 11 July.

Lewis, Rosie and Maher, Sid 2018. 'How the union army, Get Up! sealed Longman win', The Australian, 30 July.

Ludlow, Mark 2018. 'Longman's referendum on Malcolm Turnbull and Bill Shorten', Australian Financial Review, 20 July.

McKenna, Michael and Lewis, Rosie 2018. Lamb spends up big in the money seat', The Australian, 26 July.

Newspoll (various), 8 April 2018, 13 May 2018, 28 May 2018, 18 June 2018, 1 July 2018, 15 July 2018, 29 July 2018, 12 August 2018.

Oakes, Laurie 2013. Remarkable times: Australian politics 2010-2013 - what really happened. Sydney: Hachette.

Owens, Jared 2018a. 'Longman by-election: Hospital pawn in seat war'. The Australian, 2 June.

- 2018b. 'Centre holds key to LNP win in Longman'. The Weekend Australian, 7-8 July.

Ravens, Tara 2018. 'Albo's brilliant play for prime minister', news.com.au, 30 June.

Remeikis, Amy 2018. “"Lack of interest” from Liberal candidates could be gift to Labor in Longman', The Guardian, 17 May.

Richardson, Graham 2018. 'Result in Longman to shine light on Shorten's future', The Australian, 9 July.

Savva, Niki 2019a. Plots and prayers: Malcolm Turnbull's demise and Scott Morrison's ascension. Melbourne: Scribe.

_ 2019b. 'Albanese moves slowly, steadily to change', The Australian, 14 November.

SBS News (various).

Sky News 2018. 'Labor to win Longman and Braddon but would Triumph under Albanese', Newspoll report, 28 July.

Sydney Morning Herald (SMH) 2018. 'Longman by-election', 29 June.

The Guardian (various). 